\title{
A qualitative study on clinical research in Finland: fragmented governance and volume in the 2000s
}

\section{Hemminki, Elina}

2013

Hemminki , E, Veerus , P , Virtanen , J I \& Lehto , J 2013 , ' A qualitative study on clinical research in Finland: fragmented governance and volume in the 2000s ' , BMJ Open , vol. 3 , pp. Article Number: e001856 . https://doi.org/10.1136/bmjopen-2012-001856

http://hdl.handle.net/10138/165376

https://doi.org/10.1136/bmjopen-2012-001856

cc_by_nc

publishedVersion

Downloaded from Helda, University of Helsinki institutional repository.

This is an electronic reprint of the original article.

This reprint may differ from the original in pagination and typographic detail.

Please cite the original version. 


\title{
BMJ A qualitative study on clinical research Open in Finland: fragmented governance and volume in the 2000s
}

\author{
Elina Hemminki, ${ }^{1}$ Piret Veerus, ${ }^{2,3}$ Jorma Virtanen, ${ }^{2,4}$ Juhani Lehto ${ }^{5}$
}

To cite: Hemminki $E$,

Veerus $\mathrm{P}$, Virtanen $\mathrm{J}$, et al. A qualitative study on clinical research in Finland: fragmented governance and volume in the 2000s. BMJ Open 2013;3:e001856. doi:10.1136/bmjopen-2012001856

- Prepublication history for this paper are available online. To view these files please visit the journal online (http://dx.doi.org/10.1136/ bmjopen-2012-001856).

Received 27 July 2012 Revised 15 January 2013 Accepted 17 January 2013

This final article is available for use under the terms of the Creative Commons Attribution Non-Commercial 2.0 Licence; see http://bmjopen.bmj.com

${ }^{1}$ Service System Department, National Institute for Health and Welfare, Helsinki, Finland ${ }^{2}$ Department of Public Health, Hjelt Institute, University of Helsinki, Helsinki, Finland ${ }^{3}$ National Institute for Health Development, Tallinn, Estonia ${ }^{4}$ Medical faculty, University of Oulu, Oulu, Finland

${ }^{5}$ School of Health Sciences, University of Tampere, Tampere, Finland

\section{Correspondence to} Dr Elina Hemminki; elina.hemminki@thl.fi

\section{ABSTRACT}

Objectives: Although concerns over clinical research have been expressed, the governance of clinical research has been little studied. The aim was to describe research policy, volume, funding and concerns over clinical research in Finland.

Design: A qualitative study and the data were collected from various sources, including documents, statistics and semistructured expert interviews.

Setting: Finland.

Results: We found no national policy for clinical research. Many actors were responsible for facilitating, directing, regulating and funding clinical research, but no actor had the main responsibility. Health professionals were the main drivers for clinical research. The role of the health ministry was small. The ministry distributed state money for clinical research in health services (EVO-money), but did not use it to direct research. Municipalities responsible for health services or national health insurance had little interest in clinical research. The Academy of Finland had had initiatives to promote clinical research, but they had not materialised in funding. Clinical research was common and internationally competitive, but its volume had declined relatively in the 2000s. Industry was an important private funder, mainly supporting drug trials made for licensing purposes. Drug trials without an outside sponsor (academic projects) declined between 2002 and 2010. The funding and its targeting and amount were no one's responsibility. Concerns over clinical research were similar as in other countries, but it had appeared late.

Conclusions: Our results suggest fragmented governance and funding in clinical research. The unsystematic research environment has not prevented clinical research from flourishing, but the public health relevance of the research carried out and its sustainability are unclear.

\section{INTRODUCTION}

A strengthening of the scientific basis of healthcare has been called for and clinical research is a key element in achieving this. Various definitions and terms have been used for clinical research. Usually, it is defined as a subgroup of medical research

\section{ARTICLE SUMMARY}

\section{Article focus}

Using Finland as a case, we

- Describe who has responsibility for clinical research policy, that is, for the direction and oversight of research activities.

- Estimate the volume of clinical research.

- Describe who funds clinical research.

- Question if there have been any concerns over the state of clinical research.

Key messages

- We found no national policy for clinical research. Many actors were responsible for facilitating, directing, regulating and funding clinical research, but no actor had the main responsibility.

- The role of the health ministry was small. The ministry distributed state money for clinical research in health services (EVO-money), but did not use it to direct research. Municipalities responsible for health services or national health insurance had little interest in clinical research.

- Clinical research was common and internationally competitive, but volume declined relatively in the 2000s.

- Industry was an important private funder, mainly supporting drug trials made for licensing purposes. Drug trials without an outside sponsor (academic projects) declined between 2002 and 2010.

- Concerns over clinical research were similar as in other countries, but had appeared late.

Strengths and limitations of this study.

- The first study to comprehensively study clinical research governance in one country using various methods and data sources.

- The number of actors and interest groups is large, and we did not cover its entirety.

- The situation in clinical research is not static and this study covers only certain time-period (up to 2011).

and refers to research involving patients as a whole, with the aim of better diagnosis or therapy. It usually excludes medical research using only tissues and other samples, as well as sociological and psychological research on patients. However, classifications of clinical 
research vary according to the source. Also, the concepts of 'clinical trials' (clinical research with an experimental design) and 'interventions' are used variably. Some use clinical trials to refer to drug trials only.

Academic institutions and researchers in North America and later in Europe have expressed concerns over clinical research, with various initiatives attempting to overcome those problems. ${ }^{1-10}$ One initiative in Europe is the network of European academic infrastructures (ECRIN, The European Clinical Research Infrastructure Network), which is a part of the European research infrastructures (ESFRI). Concerns expressed include the poor availability of medically trained researchers, a lack of time among clinicians, the low quality of research, patients not getting the new therapies in a timely fashion, commercial biases in the funding and conducting of research and the shifting of drug trials to low income countries. A recent concern is the regulatory burden placed on clinical research, which is said to hinder research, especially non-commercial research.

Clinical trials have flourished within the pharmaceutical field, and the drug industry is the main financer and user of trials. Owing to the drug industry's commercial interests and lobbying power, and in Europe, owing to the EU mandate, drug trials have garnered special interest. The European Clinical Trials Directive (in force since 2004) has been said to make drug trials more difficult and to have decreased the number of trials sponsored by non-commercial actors. ${ }^{11-13}$

Regardless of these common concerns, only few studies have been published on the governance of clinical research or clinical trials by policy institutions. Here, policy institutions refers to institutions that are responsible for implementing public research policy, by setting priorities and aims, granting public research funding and supporting research networks and training. The only area covered thus far is publication bias and some aspects related to the availability of results. We found no previous published descriptions from Europe about what is being studied and who are the actors involved. In the USA, analyses of one type of clinical research-clinical trials-have been made using a trial register (clinicaltrails.gov). ${ }^{1} 14$

In this paper, we present the case of Finland: using a variety of sources we (1) describe the responsibilities and roles of policy institutions relevant for clinical research, (2) estimate the volume of clinical research, (3) describe who funds clinical research and (4) study any concerns over the state of clinical research. By research policy, we mean the direction and oversight of research activities. Such analysis can help to find better ways to advance relevant clinical research.

\section{Study context}

Finland is one of the Nordic welfare states, with ample public services. Its population of about five million is homogeneous and well educated. It is an ageing society and immigration is a new phenomenon. A comparison of five European countries (Denmark, Ireland, the Netherlands, Norway and Switzerland) showed that funding of research and development (R\&D) in general was high in Finland (3.73\% of GNP in 2008), but that much of it was due to R\&D carried out by commercial enterprises. ${ }^{15}$ Connections between public and private research units were more common in Finland than in the other countries by comparison. ${ }^{15}$

Finnish healthcare is largely public and is organised by municipalities, with steering from local politicians. The State regulates healthcare with laws and guidelines, state subsidies and retrospective control. Health service funding comes from a dual system: first, an area-based and communitybased tax-funded system covers most of the inpatient care and much of the outpatient care; second, national health insurance part subsidises private care, occupational care, drugs, travel reimbursement and sickness absence costs.

Finland offers significant strengths as a clinical research base, including a well-functioning healthcare system, a stable homogeneous population, commonly applied clinical care principles, a good health information system with registers, biobanks and lively research milieus in universities and many hospitals. Clinical research is regulated by the Medical Research Act of 1999 (modified in 2010) and various other national and EU-level laws and directives. All clinical research has to be considered by either locally based official research ethics committees (numbering 21 up to 2010) or a central committee.

\section{METHODS}

Data were collected by various methods; the most important are described below. In addition to these, presentations in relevant conferences, seminars and meetings and researchers' previous knowledge of the Finnish research system were used. Data collection continued till the end of 2011, with information since then used only for interpretation.

\section{Documents}

Various published reports ${ }^{9}{ }^{15-23}$ and internal documents on research and clinical research made by public bodies were reviewed; we did not have access to the internal documents of commercial bodies. Documents were analysed to identify facts and opinions on the magnitude of clinical research, its prerequisites, problems and solutions.

Unpublished data from Statistics Finland were obtained from 2011 to calculate the funding of medical and clinical research. ${ }^{24}$ Statistics Finland does not collect data on the volume of clinical research as a whole (see table 1 later). The unpaid time of researchers is not recorded or reported in detail.

\section{Expert interviews}

We chose experts by institution. We either used our previous knowledge to locate the person knowing the 
Table 1 Estimated research expenses by type of research, place and funder, Finland 2009, million Euros (\%)

\begin{tabular}{|c|c|c|c|c|c|c|c|}
\hline Place of research & Total & $\begin{array}{l}\text { State } \\
\text { budget }\end{array}$ & Municipalities & $\begin{array}{l}\text { Other } \\
\text { public* }\end{array}$ & Enterprisers†‡ & EU & Other§ \\
\hline \multicolumn{8}{|l|}{ Clinical research } \\
\hline Universities & 121 & 31 & 2 & 54 & 21 & 5 & 9 \\
\hline $\begin{array}{l}\text { Percentage of university health } \\
\text { research }\end{array}$ & $(42)$ & (30) & $(48)$ & $(51)$ & (55) & $(27)$ & $(43)$ \\
\hline \multicolumn{8}{|l|}{ Health research** } \\
\hline Universities & 287 & 102 & 4 & 105 & 38 & 17 & 20 \\
\hline Other public†† & 109 & 69 & 5 & 24 & 3 & 6 & 3 \\
\hline Enterprisersł‡ & 225 & - & - & 9 & 215 & 0.3 & - \\
\hline Total & 621 & 171 & 9 & 139 & 255 & 23 & 24 \\
\hline \multicolumn{8}{|l|}{ All R\&D } \\
\hline Universities & 1283 & 996 & NA & $\sim 92$ & $\sim 197$ & 85 & - \\
\hline Other public & 657 & 431 & NA & $\sim 45$ & $\sim 148$ & 40 & - \\
\hline Enterprisers & 4847 & 197 & NA & $\sim 16$ & 4632 & 16 & - \\
\hline Total & 6787 & 1624 & NA & $\sim 107$ & $\sim 4977$ & 141 & - \\
\hline
\end{tabular}

*State+other public.

†Domestic and foreign enterprises.

fOwn funding.

§Domestic and foreign foundations, other foreign, own resources (kotimaiset ja ulkomaiset rahastot, muu ulkomainen, omat varat).

IIncludes universities and universities of applied science; clinical research not specified for other places.

${ }^{\star *}$ In universities and other public institutes: medicine and health sciences (lääke- ja terveystieteet); in enterprises: drugs and chemical products.

††Public sector, social and health ministry.

$\ddagger \ddagger C h e m i c a l$ products, drugs (kemialliset tuotteet, lääkeainet).

Source: Statistics Finland (Tilastokeskus 2011).

EU, European Union; R\&D, research and development.

institution view and/or being knowledgeable on clinical research governance, or we asked the heads of the institutions/departments to locate the right persons. At the end of each interview, we asked further names to be interviewed (snow-ball method). We approached 26 experts, all of whom agreed to be interviewed. Of them, 15 experts were interviewed face to face and 11 via telephone. Five were from the Ministry of Social Affairs and Health, two from the Ministry of Education and Culture and three from the Finnish Medicines Agency (Fimea); eight were responsible for research authorisations and/or were from hospital research units and eight were other experts (including private healthcare research units). All experts approached or their substitutes (as recommended by the target expert) agreed for interview.

Interviews were semistructured and made by two researchers with medical backgrounds; interviews were carried out either in Finnish (EH) or English (PV). A model questionnaire was made, but each interview was tailored to the interviewee's position, expertise and interests. The project and the purpose of the interview (to obtain the views of experts) were explained and semiconfidentiality assured (names not to be used, although where necessary, the (type) of institute he/she was representing would be identified). Respondents talked freely and the order of the questions in the model questionnaire was not followed rigidly. The interviews lasted from $30 \mathrm{~min}$ to $3 \mathrm{~h}$. Notes were made during the interview and a summary of the answers was written down after the interview; the interviews were not tape recorded.
The analysis of the published and unpublished documents and the interview notes focused on identifying factual statements and opinions related to the roles, responsibilities and actions of the policy institutions with regard to clinical research, and to the prerequisites and problems they experienced to create clinical research. While not denying the prevalent social science opinion that such texts and interviewee talk not only reflect but also construct reality, in this study we were closer to the dominant tradition of the research of history. In that tradition, the factuality of an observation is strengthened by repetition of the same observation in different data sources. Thus, in order to be reported here as a result, an observation had to be found in similar enough form in more than one data source, and the factuality of the observation was not to be undermined by other observations. The researcher's own experience of acting as experts serving some of the policy institutions, that is, the Academy of Finland and university hospital administrations was helpful in making interpretations of the data. Within the family of different qualitative analysis methods, our method may be called theory-driven qualitative content analysis. ${ }^{25}$

\section{Permissions and ethics}

The whole project (MERGO Ethical review and administrative governance of clinical research) received a positive statement form the THL ethics committee (17 June 2010, amendment 27 January 2011). The statistics and 
documents used in this paper were public. All interviews were voluntary.

\section{RESULTS}

\section{Responsibility for clinical research policy}

Ministry of Health and Social Affairs (hereafter: health ministry): based on our interviews and documents, the health ministry did not consider medical or clinical research policy to be its core tasks. The content of healthcare or its evidence base was not felt to be a ministry task, but rather to be the responsibility of the care providers themselves or of the educational system (education ministry). Public health research (including health services research) was considered the ministry's task due to its research institutes. Still, no person or unit could be identified as the focal point. Several people with somewhat diffuse mandates took care of various tasks relating to research on an ad hoc basis. The vagueness was reflected in the difficulty in identifying persons for the interviews. All the people who were contacted said that clinical research was not their field, but they could not identify persons whose task it could be. Finally, five people in different departments and units were interviewed, none of whom could say that clinical research policy was their mandate. No governmental institution exists, such as the National Institute of Clinical Excellence in the UK, which is tasked with being an intermediate between clinical research and clinical practice. The preparation of clinical guidelines was 'outsourced' to a medical professional association.

However, there were several tasks and structures within the health ministry directly related to clinical research policy. They distributed and controlled the state money for clinical research in health services (EVO-money). EVO-research money is intended to compensate for extra research expenditures; the usual hospital costs are paid by municipalities, which purchase hospital services for their inhabitants. The health ministry has initiated many laws, such as on medical research, medicines, healthcare, data availability and patient rights related to clinical research. The health ministry had an internal and an external R\&D coordination group (even though it was relatively inactive at the time of interviews). At the time of the interviews, the national medical research ethics committee was within the health ministry (administratively under the National Advisory Board on Social Welfare and Health Care Ethics ETENE set by Ministry) and the ministry granted permissions for research projects that used healthcare data. Later, the latter two functions have been transferred to institutions operating under the health ministry.

The health ministry had not used EVO-money for directing research, that is, to decide which kind of projects or purposes the money is used for. EVO-money distribution was considered an administrative task to compensate for medical research costs, not a mechanism to improve clinical research or healthcare. One civil servant was responsible for preparing the health ministry's decision for distributing the money to the hospital districts, as part of his many duties. The Ministry of Education and Culture (hereafter: education ministry) was not consulted in the use of EVO-money.

A number of proposals have been made for changing the health ministry's passive role in the distribution of EVO-money, but up until 2011, legislation on health services had not changed significantly. Opposition from the university hospitals combined with few staff in the health ministry with personal experience of clinical or health services research had contributed to the inactivity. The 2011 law stated for the first time that the health ministry has to define, jointly with the five university hospitals/ hospital districts, the priority areas and aims of EVO health research. The health ministry should also oversee that the areas and aims are followed. However, according to the interviews, the resources for this task will remain modest, and so may not allow the ministry to completely fulfil this responsibility.

The health ministry did not collaborate closely with the other actors in research policy, such as with the education ministry, health services or university research units. Most cooperation had been with the Academy of Finland, which is an important public research funder that operates under the education ministry. European Union (EU) health matters were divided among various people and departments in the health ministry. The ministry role in EU research matters was modest at the time of the interviews; previously, the role used to be larger.

Ministry of education and culture (education ministry): Finland does not have a ministry of science, so research matters were dealt with in various ministries, particularly within the education ministry and the Ministry of Employment and Economy (TEM). The education ministry had responsibility for academic research and it distributed state money to universities, polytechnics and the Academy of Finland (the grant-giving agency). The education ministry did not take an (open) stand on research prioritisation. No separate activities on clinical research could be identified even though the education ministry had had some other targeted projects, such as biotechnology centres. The education ministry oversaw the education of health professionals (future clinical researchers), but had not taken particular responsibilities for research activities in healthcare.

The education ministry worked jointly with the Ministry of Employment and Economy in R\&D matters, particularly in regard to innovations and EU matters. These two ministries jointly run a research policy body (TIN, see below).

Ministry of Employment and Economy (TEM) is responsible for the promotion of innovations and EU relations, jointly with other relevant ministries. An important public funder (TEKES) operates under this Ministry (see below). We did not interview TEKES as other interviewees reported that TEM-support was generic and not 
specifically related to medical or clinical research. Clinical research had not been a Finnish focus in EU research matters.

Research and Innovation Council (TIN) is a body under the prime minister that advises the government on research and innovation policy. Its Secretariat is divided between the education ministry and TEM. In recent years, its focus has been on improvement of the national economy and technological research. In medicine, biomedical research has been an issue, but not clinical research.

Finnish Medicines Agency (Fimea) (hereafter: drug agency) has the task of reviewing and approving interventional research with unlicensed drugs or new indications (hereafter: drug trials); device and food control is the responsibility of other government agencies. The drug agency has interpreted the EU Clinical Trials Directive broadly to also cover other types of drug research, such as surveys on drug prescribing and use. The drug agency itself or other interviewed actors did not consider its task to be the facilitation of academic (non-commercial) drug research.

The documents, interviews and observations showed that the drug agency had a 'regulatory mind'; ensuring compliance with national and EU laws and rules were important, emphasising the drug agency's key function of drug control. Even though the interviewed civil servants were well aware of the concerns over drug trials, our interpretation was that they had been relatively passive in finding solutions both nationally and internationally.

The drug agency had recognised the problems of noncommercial drug trials and had noticed their decline in recent years. They offered simpler procedures for research with licensed drugs and extra advice for academic researchers. Academic researchers could also ask for a waiver of the handling fee. However, it seemed that the agency considered these as favours on their part and not a primary duty.

Health services: as municipalities organise and pay for most health services, they have an interest in the quality and orientation of the services. But municipality politicians or civil servants did not have an interest in research, not even when directly relevant to the service provision. Clinical research has been delegated to other actors, particularly to the leading physicians in the healthcare units. A requirement for most leading positions in public hospitals is academic merit, which has stimulated physicians to do research, even though not particularly clinical research.

Most university hospitals have clinical research units, financed by overheads from outside grants, EVO-money (state subsidies) and hospital district support. Clinical research units have served mainly their own institutes and protected hospital interests. They could be classified as public business brokers or public research contract organisations. The business concept, administrative status and activity level varied by hospital. The origins were in contract research with the drug industry, but some units had broadened into providing many-sided support functions also covering non-commercial research. Clinical research units were important in facilitating research administration, but they did not have research policy functions. Their identity was closer to researchers than research policy makers and their formal and informal connections to the national actors were small.

In the past few years, international and national joint initiatives and projects have evolved to advance drug trials in Finland. Even though these initiatives have been specifically targeted to drug trials, the suggested measures are likely to advance clinical research in general, particularly through better infrastructure. One hospital district has established jointly with some other bodies a public company (FinnMedi Research Ltd), which also ran national activities, such as a network of researchers on paediatric medicines and FinnTrials (see later TEKES).

Interviews and documents suggested that clinicalparticularly commercial-research has increasingly shifted to private healthcare. Some of the largest private chains have been proactive in helping sponsors and researchers to find each other and they have research governance offices with business and law expertise. Research has been an incentive in recruiting and keeping physicians in the clinic.

Physician researchers: senior researchers worked as experts in various functions, and their influence occurred via other actors, such as the health ministry, drug agency, health services research units, various grant-giving bodies and in international organisations. In addition to these indirect influences, physicians' professional organisations had established an expert group to solve problems in clinical research, ${ }^{21} 23$ and various activities to improve conditions, visibility and funding have been proposed since 2010.

There were tight and complex relationships between university hospitals and university medical schools. An important lobby for clinical research has been the medical schools and their Deans. But medical schools have medical education as their first priority. In research policy, they have remained in the shadow of the biotechnology centres attached to the university hospitals and universities, which have been a priority in regional and national research and innovation policy.

\section{Volume of clinical research}

An international evaluation concluded that the quality and quantity of Finnish clinical research were high compared with other countries, but the volume was declining relatively in the 2000s. ${ }^{16}$ The number of medical publications per inhabitant was high, ${ }^{16}$ and Finland ranked seventh worldwide in the citation analysis of clinical medicine research. ${ }^{16}$ Vaccination trials and public health research have been considered special strengths. ${ }^{9}$

According to a national survey of physicians in 2006, ${ }^{22}$ a high proportion of physicians reported engagement in 
research (clinical research was not specified): $46 \%$ of hospital physicians, $20 \%$ of private practitioners, $17 \%$ of physicians in occupational care and 13\% in public health centres reported participation in research. The time frame was not defined, but the question formulation suggested current research. Research was more common outside the main work than as a part of it. Surveys of physicians in 2006 and 2011 (unpublished surveys, TEKES seminars 2011 and 2012) suggested that in many hospitals and health centres, conditions for doing clinical research were getting worse, particularly due to the burden of routine patient care and lack of time.

In the late 1990s and first part of the 2000s, trials with new drugs were common in Finland (10-fold higher than expected on the basis of the population size. ${ }^{26}$ According to the statistics of the national drug agency, the total number of clinical trials started were relatively steady from 2001 to 2006 (varying between 238 and 293) but then declined thereafter (209 in 2010). ${ }^{27}$ The largest declines were in the phases 2 and 1 trials. The trials without an outside sponsor (academic projects) declined between 2002 and 2010 from about 90 to 40 .

There are no ready data on the money or other resources used in clinical research in Finland. Furthermore, classification and expenditure recording differ by institutes. Based on the raw data from Statistics Finland, we constructed table 1, which shows recorded expenditure by the funder and sector. Clinical research was specified only for research in universities, in which it represented $42 \%$ of all health research. Most university clinical research was funded by the public sector and only $17 \%$ was funded by enterprises. However, when all health research, including research outside universities (54\% of health research was outside universities), was included, $41 \%$ was funded by enterprises and $36 \%$ was made within enterprises. Compared with all R\&D costs in Finland, health research in enterprises was rarer than overall $(71 \%$ of R\&D was made within enterprises and an estimated $73 \%$ was funded by enterprises).

A calculation from 1997 to 1998 estimated that of the expenditure in health research (about EUR 277 millions), $24 \%$ was funded by industry. ${ }^{19}$ This suggests that either industry funding for health research has (proportionally) increased, or more likely, that figures were calculated differently. We found no previous estimates of funding specifically of clinical research.

\section{Funding of clinical research}

Industry, particularly the drug industry, was an important private funder, mainly supporting drug trials made for licencing purposes. We did not find any more detailed public information of industry investment in medical research than the rough figures given in table 1.

The health ministry $(\mathrm{MOH})$ distributed to hospital districts the state subsidies earmarked for medical research in public healthcare (EVO-research money). A key concern brought up by the health ministry, the hospital districts and researchers was the decline of the subsidy over the years, both in absolute terms and as purchasing power. The total amount was about EUR 60 million in $1999^{19} 20$ and EUR 40 million in $2009^{20}$ and in 2010. ${ }^{28}$ The 2011 budget proposed further cuts (to EUR 35 million).

The basic principles for allocating the subsidies were the same between 1994 (when the system was introduced) and 2010, although the details varied. At the time of the interviews, subsidies were given to the five university hospital districts by the number (and impact factor of the publication forum) of publications in the previous year. The university hospital districts distributed the money based on their own decisions, to be used for medical and nursing research in their area. Part of the money was given for infrastructure, part to care units based on publication activity and part for competing individual projects. All researchers working in healthcare within the university hospital area were eligible to apply. Clinicians considered EVO-money as an important support for research funding. Money was commonly used for clinicians' salaries, enabling them to be free from clinical work for short time periods, though usually still working within the same clinic.

The key persons in distributing the money were leading university professors, but the criteria deciding body and transparency of the process varied by the university hospital. The key criterion, number of previous publications graded by the type of the publication forum, was criticised. A problem from the point of view of clinical research was that the competitiveness of the strong basic biomedical research, by the EVO criterion, was much better than that of clinical research.

TEKES (The Finnish Agency for Technology and Innovation) is under the Ministry of Employment and Economy (TEM) and was the biggest public funder for research and innovation. It aimed to promote innovations (mainly commercial) and research that might lead to innovation, in collaboration with enterprises. It has supported basic biomedical research aiming for commercial products (biotechnology), telemedicine and other ICT support for clinical practice, and the development of new business models for private clinical service providers. Support for the building of projects in biotechnology centres attached to university hospitals was the main role of TEKES in the biomedical area. Support for clinical research was marginal.

The 2008-2011 Pharma-programme was established with the aim of facilitating drug research. It included a section on clinical trials and as a part of the FinnTrials project, it aimed to improve the infrastructure for (commercial) clinical research. It aimed to harmonise the procedures in contract research and other administration in the five university hospitals. TEKES also has activities aimed at locking commercial enterprises into drug research in Finland.

The Academy of Finland is a grant-giving body under the education ministry and covers all disciplines. Owing to 
the way the Academy is organised and its experts chosen, ${ }^{29}$ the Academy represents the research community and not only the ministry. Besides distributing grants, the Academy has research policy functions. It produces policy documents for the whole research community, but its main policy impact is through the funding it gives. Since the 1990s, the Academy and its health council have had initiatives to promote clinical research, including the education of the clinical researcher. ${ }^{16}$ Regardless of the various initiatives, it has not resulted in many extra grants. Clinical research competes for grants with other health research and its competitiveness has not been high with the Academy criteria. The Academy see its main role as funding basic research, while clinical research is often categorised as applied research. Furthermore, while the Academy is the main funding source for research in social sciences, humanities and basic (natural) science, its proportion of funding, and thus impact, for health and technology research is much lower.

In addition to these main public funders, there were various other public funders and non-profit foundations supporting clinical research, mainly through competitive bids or grants. Their grant volumes, however, were modest.

\section{Concern over clinical research}

Based on our own expert interviews and recent initiatives by various bodies and published reports, ${ }^{16-18} 20212330$ it was clear that concerns existed over the magnitude of and circumstances around clinical research. The problems cited were the same as in other countries: a declining number of clinical researchers, difficulty in recruiting medical students into research, modest infrastructure and a lack of noncommercial funding for clinical research. A particular concern had been the lack of clinical researchers. However, the concerns were expressed late and mostly by researchers or the Academy of Finland. (The most active discussions seemed to have taken place after our data collection closing date, December 2011.)

Government bodies other than the Academy of Finland or TEKES have not acted to promote clinical research, and concerns over this were not brought up in our interviews. When probed, some civil servants were aware of the discussion elsewhere, but clinical research was not felt to be their mandate or a key problem. This lack of concern was true even in regard to the health ministry's distribution of EVO-research money, which has declined notably over the years. Finnish public bodies and researchers have participated in European-level activities aimed at facilitating clinical research, but according to the documents and our interviews, they have not been the key actors.

Finland is a Nordic country and at the Nordic level, various initiatives for improving clinical research have been taken recently, ${ }^{17}{ }^{18}$ but none have yet led to concrete actions. An initiative of the Nordic Council of
Ministers was to strengthen Nordic multicentre clinical research and, by extension, also to support national clinical research. ${ }^{17} 18$ The reasons behind the initiatives included the usual ones, such as the decline of drug trials, as well as the need to have more publicly funded clinical research in the Nordic countries.

None of our interviews or documents showed that the possible problems caused by commercial actors, particularly the drug industry, in sponsoring clinical research were being tackled. If it came up, commercial funding and practices facilitating it were considered important.

\section{DISCUSSION/COMMENTS}

\section{Strengths and shortcomings of the study}

The situation in regard to research changes constantly. This applies particularly to clinical research, where solutions for the problems identified are sought. We aimed to describe the situation in a single country over the main period of data collection (2009-early part of 2011), with later changes not included. For example, the research community as well as physicians associations in Finland have recently started a public campaign for more state money (EVO-money) as well as seeking other improvements to facilitate clinical research.

A problem for our study was how various sources and actors defined medical and clinical research. Different people might have had different activities in mind when considering medical and clinical research. The data and classification of clinical research in statistics were deficient. The classification and availability of statistical data are a problem not only in Finland. ${ }^{31}$

The number of actors and interest groups in clinical research is large and we did not cover it in its entirety in our interviews or document gathering. As the clinical research policy turned out to be very fragmented, in hindsight, we could have interviewed experts from more institutions, such as the Ministry of Employment and Economy and its research funding arm TEKES, the Academy of Finland, municipality associations and professional associations. However, as the data from different sources gave a relatively similar picture, we think that our findings give a fair picture of the situation in Finland at the end of the first decade of the millennium. However, we were not able to articulate all the nuances or differentiate between personal and institutional views.

\section{Research policy}

We found no coordinated national (or regional) policy for clinical research. Many actors had responsibilities for facilitating, directing, regulating and funding clinical research, but there was no common body or single actor to coordinate the policies of different actors. At the national level, various ministries were involved, though the role of the health ministry was passive. In public health services, municipalities (their political or administrative bodies) responsible for services had little or no interest in research policy. Individual health professionals were largely the 
drivers in research matters. Likewise, in the private (and occupational care) sector, the professionals were the main actors, while the health insurance body had little interest in clinical research. Our findings support a recent recommendation by a professional expert group that improvement of clinical research will require a change in attitude among health services (municipalities), as research is claimed to guarantee the quality and efficacy of hospitals and physicians' work. ${ }^{21}$

Our results suggest fragmented governance and funding of clinical research. They also suggest a lack of strong interest groups, other than the drug industry for drug trials. Patients or patient advocates were not seen, and although healthcare organisations gave resources (mainly time), they did not have a specific research policy; for government and public funders, clinical research was a marginalised issue. Only the clinicians were concerned. As such, the fragmentation of public policies between different public actors is not specific to clinical research or research in general. It is a general tendency in the trend described as 'from government to governance'. ${ }^{32}$ However, in the case of Finnish clinical research, the new modes of governance were largely missing.

The fragmentation of governance and funding seems to be linked to a number of institutional characteristics both in health services and research policy in Finland. The decentralised structure and multichannel funding of health services may prevent a consolidated clinical research policy by the service system. The institutional fragmentation of governmental health research policy to at least three different ministries (Education and Culture, Employment and Economy and Social Affairs and Health) may be a second source of fragmentation. A third explanation may be the weak capacity of the clinical researcher community and the medical faculties to create a common pressure on the policy makers and institutions to overcome the fragmentation linked to the competition within the researcher community for scarce research resources.

Our finding of a fragmented governance of clinical research is not likely to be only a Finnish phenomenon. Various countries are looking for solutions to how best to target and use limited research resources in an optimal way. ${ }^{133}{ }^{34}$ However, an international comparative study of national clinical research policies and policy institutions would be needed to verify whether Finland is an exception or an example of a typical situation in governing and funding clinical research.

\section{Volume and funding}

However, international comparisons show good outputs of research, even though declining recently. ${ }^{16}{ }^{35}$ So this unplanned system has worked (in the past), judging by the publication and citation numbers. No studies exist, however, that have compared the societal usefulness and quality of the research done: were the study questions relevant to health and were they constructed in a way that adequately answered the questions posed?
In the USA, the National Institutes of Health are an important biomedical research funder, including of clinical research ${ }^{2}$; in Finland, there is no corresponding institute. Funding for clinical research came from various sources and was quite fragmented. The drug industry plays an important role. Otherwise, much seems to be done in the clinician's own time and with small-scale funds.

As healthcare organisers and funders did not have a policy interest in research, the research topics must have been chosen according to the funders' and researchers' own interests. Commercial research is likely to be biased towards the commercial sale of products. ${ }^{36}$ Dorman et $a l \mathrm{~s}^{37}$ analysis of trials in acute stroke in 1955-1995 showed that only $12 \%$ tested non-drug interventions, while Tallon $e t a l^{8}$ concluded that the research agenda for osteoarthritis reflected the priorities of commercial funders. Analyses from other countries suggest wastage in medical research at various stages, including in the form of studying trivial questions (from a public health point of view) or leaving results unpublished. ${ }^{34} 39$

\section{Concern over clinical research}

In Finland, public discussion on the state of clinical research has appeared late, and it has not been particularly visible. State and health service interests have been low. Statistical data suggest a reduction in the number of new drug trials in the latter half of the 2000s, and particularly those without outside sponsorship have declined. Our own unpublished data from 2002 to 2007 (Hemminki et al, unpublished data 2012) have shown that the number of clinical research projects is large, but nevertheless declining.

We conclude that clinical research in Finland has been strongly active, but is apparently losing some footholds. It seems to have been researcher based and national or institutional planning and support is weak. To strengthen clinical research, a better recording of research funding and activities would be needed to plan actions. A coordinating institution with responsibility for recording medical/ health research, including clinical research, might help in identifying problems and alerting to the need for action. However, the results do not suggest that more rules and coordination as such, without better resources, would end in more relevant clinical research.

Acknowledgements The study was funded by an Academy of Finland grant (28356). We thank the interviewees for their time and Joel Lecxhin and Elena Regushevskaya for their comments.

Contributors EH conceptualised the study and data analysis, interpreted findings and drafted the manuscript. PV and JV conducted the analysis and participated in the interpretation of findings. PV, JV and JL participated in the conception and commented on the article. All authors read and approved the final manuscript.

Funding The study was funded by an Academy of Finland grant (28356).

Competing interests None.

Provenance and peer review Not commissioned; externally peer reviewed.

Data sharing statement No additional data are available. 


\section{REFERENCES}

1. IOM (Institute of Medicine). Transforming clinical research in the United States: challenges and opportunities: workshop summary. WashingtonDC: The National Academies Press, 2010.

2. IOM (Institute of Medicine). Public engagement and clinical trials: new models and disruptive technologies: workshop summary. WashingtonDC: The National Academies Press, 2011.

3. The Academy of Medical Sciences. New pathway for the regulation and governance of health research. London, 2011.

4. Kramer JM, Smith PB, Califf RM. Impediments to clinical research in the United States. Clin Pharm Ther 2012;91:535-41.

5. Gotzsche PC. Why we need easy access to all data from clinical trials and how to accomplish it. Trials 2011;12:249.

6. European Science Foundation. Investigator-driven clinical trials. Setting science agendas for Europe. ESF Report, Strasbourg, 2009.

7. European Science Foundation. ESF-EMRC Position Paper: Proposal for a revision of the "Clinical Trials Directive" (2001/20/ EC) and other recommendations to facilitate clinical trials. Strasbourg, December 2011.

8. Swan J, Robertson M, Evans S. Managing clinical research in the UK. Warwick: Warwick Business School, December 2009.

9. Gestrelius S. Nordic cooperation in clinical research - opportunities and challenges. Nordic Forum for Innovation in Health Care and Medicine, 2009. http://www.regjeringen.no/pages/16778530/ 200900715_D1_V10.pdf (accessed 2 Jul 2012).

10. Patsopoulos NA, loannidis JPA, Analatos AA. Origin and funding of most frequently cited papers in medicine: database analysis. $B M J$ 2006;332:1061-4.

11. Brendt L, Hakansson C, Bach KF, et al. Effect of European Clinical trials Directive on academic drug trial in Denmark: retrospective study of applications to the Danish Medicines Agency 1993-2006. BMJ 2008;336:33-5.

12. EFGCP European Forum for Good Clinical Practice: Impact of clinical research of European legislation. Final report of ICREL to European Commission, Directorate Research, 2009. http://www.myesr.org/html/ img/pool/Final_report_ICREL.pdf (accessed 2 Jul 2012).

13. Apperely J. Has the European clinical trials directive been a success? BMJ 2010;340:937-8.

14. Califf RM, Zarin DA, Kramer JM, et al. Characteristics of clinical trials registered in ClinicalTrials.gov, 2007-2010. JAMA 2012;307:1838-47.

15. Viljamaa K, Lehenkari J, Lemola $\mathrm{T}$, et al. Tutkimuspolitiikan välineet ja käytännöt-viiden maan vertailu. Suomen Akatemian julkaisuja 2/ 10. Helsinki: Suomen Akatemia, 2010.

16. Academy of Finland. Clinical research in Finland and Sweden. Helsinki: Publications of the Academy of Finland, 2009.

17. Eriksen II, Kierulf K. A study of clinical trials in Nordic arena. Oslo: Nordic Innovation Centre, 2011. http://www.nordicinnovation.net (accessed 2 Jul 2012).

18. Fellström B. Nordisk samarbete om kliniska multicenterstudier. Nordiska ministerrådet, 2011, unpublished document. http://www. regjeringen.no/pages/16778530/200900715 D1 V1.pdf (accessed 2 Jul 2012).

19. Kekomäki M. terveystieteelliseen tutkimukseen käytettävä valtionosuus. Työryhmämuistioita 2001:3. Helsinki: Sosiaali- ja terveysminsiteriö, 2001.

20. Löppönen $\mathrm{P}$, Lehvo A, Vaahtera K, et al. Suomen tieteen tila ja taso 2009. Helsinki: Suomen Akatemia, 2009.

21. Renkonen R, Björkroth J, Helsve $O$, et al. Riittääkö Suomessa lääkäritutkijoita? Duodecim 2011;127:1003-9.

22. Suomen Lääkäriliitto: Lääkärikysley 2006. Tilastoja. http://www. laakariliitto.fi (accessed 25 May 2011).

23. Visakorpi T, Jalkanen $\mathrm{S}$, Laakso $\mathrm{M}$, et al. Kliininen tutkimus Suomessa: tutkimuksen rakenteet. Duodecim 2011;127:957-8.

24. Tilastokeskus. Statistical databases 2011. http://pxweb2.stat.fi/ Database/statFin/ttt/tkke_fi.asp (accessed 4 Jun 2011).

25. Hsiu-Fang H, Shannon SE. Three approaches to qualitative content analysis. Qual Health Res 2005;15:1277-88.

26. Keinonen T. Clinical drug trials in Finland. Quality and characteristics. Kuopio: Kuopio University Publications A, Pharmaceutical Sciences 66. University of Kuopio, 2003.

27. Fimea. Clinical trials statistics. http://www.fimea.fi/instancedata/ prime_product_julkaisu/fimea/embeds/fimeawwwstructure/19618_ kliinisten_laaketutkimusten_tilasto_2010.pdf (accessed 14 May 2012).

28. Valtion talousarvioesitykset. http://www.vm.fi/budjetti (accessed 5 Oct 2011).

29. Academy of Finland. http://www.aka.fi (accessed 15 May 2012).

30. Miettinen PJ, Heikinheimo M. Tutkimus kärsii sairaalamaailman vaatimusten puristuksessa. Suomen Lääkärilehti 2011;44:3284

31. Moses H, Dorsey FR, Matheson DHM, et al. Financial anatomy of biomedical research. JAMA 2995;294:1333-42.

32. Bouckaert G, Peters G, Verhoest K. The coordination of public sector organizations. Shifting patterns of public management. Houndmills: Palgrave McMillan, 2010.

33. McCoy D, Sanders D, Baum F, et al. Pushing the international health research agenda towards equity and effectiveness. Lancet 2004;364:1630-1.

34. Chalmers I, Glazsiou P. Avoidable waste in the production and reporting of research evidence. Lancet 2009;374:86-9.

35. Opetus- ja kulttuuriministeriö. Tutkimuksen tuottavuuden kehitys Suomen yliopistossa. Opetus- ja kulttuuriministeriön julkaisuja 2011:2. Helsinki: Opetus- ja kulttuuriministeriö, 2011.

36. Avorn J. Torcetrapid and atrovastin-should marketing drive the research agenda? NJEM 2005;352:2574-6.

37. Dorman PJ, Counsell C, Sandercock P. Reports of randomized trials in acute stroke, 1955 to 1995 . What proportions were commercially sponsored? Stroke 1999;30:1995-8.

38. Tallon D, Chard J, Dieppe P. Relation between agendas of the research community and the research consumer. Lancet 2000;355:2037-40.

39. Chalmers I. Current Controlled Trials: an opportunity to help improve the quality of clinical research. Curr Control Trials Cardiovasc Med 2000;1:3-8. 


\section{BMJ Open}

\section{A qualitative study on clinical research in Finland: fragmented governance and volume in the 2000s}

Elina Hemminki, Piret Veerus, Jorma Virtanen and Juhani Lehto

BMJ Open 2013 3:

doi: 10.1136/bmjopen-2012-001856

Updated information and services can be found at:

http://bmjopen.bmj.com/content/3/2/e001856

\section{References This article cites 17 articles, 4 of which you can access for free at: http://bmjopen.bmj.com/content/3/2/e001856\#BIBL}

Open Access This is an open-access article distributed under the terms of the Creative Commons Attribution Non-commercial License, which permits use, distribution, and reproduction in any medium, provided the original work is properly cited, the use is non commercial and is otherwise in compliance with the license. See: http://creativecommons.org/licenses/by-nc/3.0/ and http://creativecommons.org/licenses/by-nc/3.0/legalcode
Email alerting Receive free email alerts when new articles cite this article. Sign up in the service box at the top right corner of the online article.

Collections

Articles on similar topics can be found in the following collections

Epidemiology (1619)

Health policy (510)

Qualitative research (528)

\section{Notes}

To request permissions go to:

http://group.bmj.com/group/rights-licensing/permissions

To order reprints go to:

http://journals.bmj.com/cgi/reprintform

To subscribe to BMJ go to:

http://group.bmj.com/subscribe/ 